\title{
PERSPECTIVE
}

\section{Inflammation and lithium: clues to mechanisms contributing to suicide-linked traits}

\author{
E Beurel ${ }^{1,2}$ and RS Jope ${ }^{1,2}$
}

\begin{abstract}
Suicide is one of the leading causes of death in the United States, yet it remains difficult to understand the mechanistic provocations and to intervene therapeutically. Stress is recognized as a frequent precursor to suicide. Psychological stress is well established to cause activation of the inflammatory response, including causing neuroinflammation, an increase of inflammatory molecules in the central nervous system (CNS). Neuroinflammation is increasingly recognized as affecting many aspects of CNS functions and behaviors. In particular, much evidence demonstrates that inflammatory markers are elevated in traits that have been linked to suicidal behavior, including aggression, impulsivity and depression. Lithium is recognized as significantly reducing suicidal behavior, is anti-inflammatory and diminishes aggression, impulsivity and depression traits, each of which is associated with elevated inflammation. The anti-inflammatory effects of lithium result from its inhibition of glycogen synthase kinase-3 (GSK3). GSK3 has been demonstrated to strongly promote inflammation, aggressive behavior in rodents and depression-like behaviors in rodents, whereas regulation of impulsivity by GSK3 has not yet been investigated. Altogether, evidence is building supporting the hypothesis that stress activates GSK3, which in turn promotes inflammation, and that inflammation is linked to behaviors associated with suicide, including particularly aggression, impulsivity and depression. Further investigation of these links may provide a clearer understanding of the causes of suicidal behavior and provide leads for the development of effective preventative interventions, which may include inhibitors of GSK3.
\end{abstract}

Translational Psychiatry (2014) 4, e488; doi:10.1038/tp.2014.129; published online 16 December 2014

\section{INTRODUCTION}

In 2010, suicide was the 10th leading cause of death in the United States, accounting for more than 38000 deaths, the suicide rate increased steadily during the previous 10 years, and an astounding approximately one million people in the US made a suicide attempt (Centers for Disease Control and Prevention website). Thus, it is evident that suicide is a major health problem that is not adequately treated, as well as being poorly understood. Clearly, there is a crucial need to develop improved strategies to understand the conditions that elicit suicidal behavior and to develop effective interventions.

Suicidal behavior is often, but certainly not always, associated with psychiatric illnesses, particularly major depression, bipolar disorder and schizophrenia. For example, a strong association was indicated by the finding that suicide is $60 \%$ comorbid with mood disorders, ${ }^{1}$ and the risk of suicide is at least 15 times higher in patients with bipolar disorder than for the general population. ${ }^{2}$ However, the perplexing question remains as to what differentiates the suicidal person from those with similar conditions that are not suicidal. This issue has led to numerous studies attempting to identify behavioral characteristics that contribute to suicidal behavior. Among the key characteristics that have been identified to be associated with suicidal behavior, impulsiveness, aggression and feelings of helplessness or depression demonstrate particularly strong links. ${ }^{1,3-9}$ These associations raise the possibility that identification of mechanisms and therapeutic interventions that regulate these characteristics may provide insight into the causes of suicidal behavior and lead to methods for early detection and intervention. In this regard, there is increasing evidence that abnormal activation of the inflammatory system is linked to each of these individual behaviors in animal models, and to suicidal behavior in humans.

Here, we review evidence suggesting that inflammation may be a key factor precipitating suicidal behaviors in response to initiating stressors, we assess key aspects of suicidal behaviorlinked endophenotypes that have been studied in rodents, and we examine the effects of lithium intervention that appears to diminish suicide-linked behaviors.

\section{STRATEGIES TO STUDY SUICIDAL BEHAVIOR IN ANIMAL MODELS}

The very nature of suicide limits direct investigation except postmortem, thus gaining a better understanding of suicidal behavior requires the development of indirect strategies. Two feasible approaches include studies in animal models of mechanisms that regulate suicide-associated behaviors, and studies of the mechanism of action of drugs that alter suicidal behavior. Thus, although suicide cannot be directly studied in animal models, rodents can be used to study factors that regulate suiciderelevant behaviors or endophenotypes. Using the endophenotype approach to investigate complex behaviors associated with numerous psychiatric and neurological conditions has been discussed by many investigators in a variety of fields, ${ }^{10,11}$ and although not perfect, it remains the primary strategy available for studies in rodents. Thus, a better understanding of suicidal

\footnotetext{
${ }^{1}$ Department of Psychiatry and Behavioral Sciences, Miller School of Medicine, University of Miami, Miami, FL, USA and ${ }^{2}$ Department of Biochemistry and Molecular Biology, Miller School of Medicine, University of Miami, Miami, FL, USA. Correspondence: Professor RS Jope, Miller School of Medicine, University of Miami, 1011 NW 15 th Street, Gautier Building Room 416, Miami, FL 33136, USA.

E-mail: rjope@med.miami.edu

Received 18 August 2014; revised 21 September 2014; accepted 26 October 2014
} 
behavior may benefit from studies of endophenotypes in rodents, particularly impulsive behavior, aggression and depression-like behaviors that have been linked to suicidal behavior. Another strategy to examine mechanisms regulating suicidal behavior is to consider the actions of an agent that reduces attempted and completed suicides. Substantial evidence demonstrates that lithium, the classical mood stabilizer used to treat bipolar disorder, reduces suicidal behavior and mortality during long-term treatment. 5,12 This conclusion is supported by several meta analyses and has been reported in patients with unipolar and bipolar depression (the patient populations most often treated with lithium), in responders and nonresponders to the mood stabilizing action of lithium, and the antisuicidal effect of lithium is not matched by other mood stabilizers or antidepressants. ${ }^{6,8,13-16}$ Furthermore, several studies have found that relatively high levels of lithium in the public drinking water are associated with reduced risk of suicide in the general population. ${ }^{17}$ Thus, studies in rodents of individual behaviors associated with suicidal behavior, in conjunction with studies of lithium, which is able to diminish suicidal behavior, provide feasible investigative strategies to better understand the underlying causes of suicidal behavior and to develop effective interventions.

\section{STRESS INDUCES INFLAMMATION WHICH IS ASSOCIATED WITH SUICIDAL BEHAVIOR}

Stress is a common precursor of suicidal behavior. ${ }^{18}$ Stress also increases inflammation, and inflammation is linked to increased impulsive, aggressive and depressive behaviors, leading to the hypothesis that stress-triggered inflammation has an important role in provoking suicidal behavior (Figure 1). Multiple types of psychological stress have been shown to cause activation of the inflammatory response, which is indicated by elevated levels of

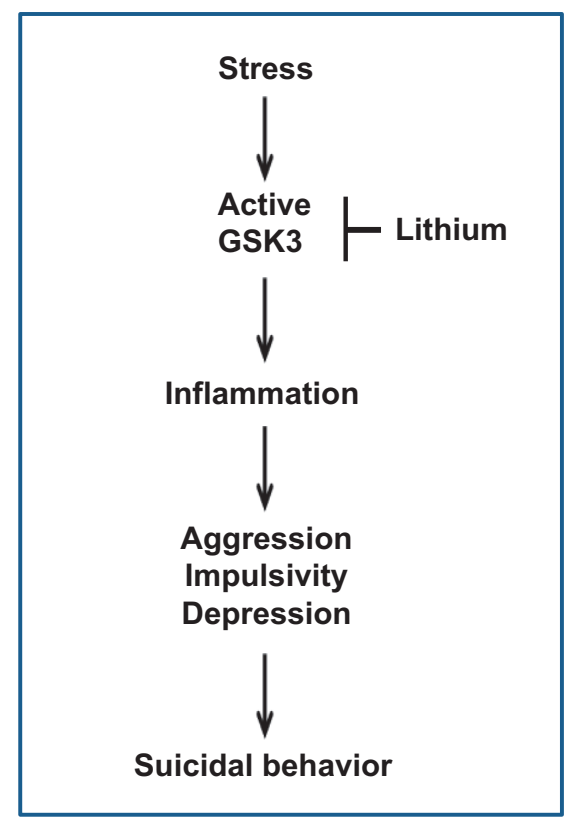

Figure 1. Scheme of a potential mechanistic pathway that may lead to suicidal behavior. The scheme displays a hypothetical component of mechanisms contributing to suicidal behavior. Stress is established to cause activation of GSK3 in rodent brain, and lithium is an established inhibitor of GSK3, which we propose may contribute to its antisuicidal actions. Active GSK3 promotes inflammation, and we hypothesize that inflammation, one of multiple signaling systems regulated by GSK3, contributes to provoking components of suicidal behavior, such as aggression, impulsivity and depression. GSK3, glycogen synthase kinase-3. inflammatory cytokines. ${ }^{19-45}$ However, comparative studies have not been reported to determine if different types of stress induce different patterns of inflammatory cytokine production, and which inflammatory molecules are most closely associated with suicidal behavior. The common finding that stress induces inflammation has been interpreted in evolutionary terms as a logical mechanism to enhance survival. Historically, many stressors had the potential to lead to injury and infection, therefore pre-activation of the immune system would enhance survival and recovery. ${ }^{46}$ However, as psychological stress has increased in modern societies, and drugs are available to combat life-threatening infections, these evolutionary mechanisms to improve survival after injury may now have deleterious effects on behaviors, including promotion of multiple suicide-linked behaviors, as discussed below.

Except for the initial insult, stress appears to utilize many of the same mechanisms as pathogens to induce an inflammatory response, although much still remains to be learned about the details of the stress-induced signaling pathway. The stress response is most well-characterized for signaling through Tolllike receptor 4 (TLR4), the receptor for lipopolysaccharide (LPS), which is the most widely used agent to study inflammation experimentally and is the major cause of sepsis. TLR4 is activated by both pathogen-associated molecular patterns of microbes, and insult-induced endogenous ligands, called danger- or damageassociated molecular patterns (DAMPs). ${ }^{47}$ DAMPS induce TLR4 signaling outcomes that respond to the need for rapid dangerrecovery and restoration of homeostasis. ${ }^{48}$ DAMPs that activate TLR4 include a broad range of molecules, such as heat-shock proteins, ${ }^{49}$ hyaluronan oligosaccharides, ${ }^{50}$ high-mobility group protein box-1, ${ }^{51}$ modified lipids ${ }^{52}$ and several others, which are produced by a variety of stressors in the central nervous system as well as peripherally. Thus, stress-induced DAMPs can set in motion an inflammatory response that appears to be equivalent to that induced by pathogens. TLR4 is expressed by microglia, astrocytes and neurons, as well as immune cells. ${ }^{48,53-57}$ TLR4 expression is dynamic and is often upregulated in conditions that are associated with increased levels of pathogen-associated molecular patterns or DAMPs, ${ }^{52,58}$ including evidence of dynamic changes in the expression of TLR4 in the brain. For example, TLR4 expression in rodent brain increased in response to ischemia/reperfusion injury, which was partially attributed to DAMPs arising from oxidative stress. ${ }^{55,59}$ Furthermore, chronic mild stress increased TLR4 expression in rat prefrontal cortex ${ }^{42}$ and administration of a TLR4 antagonist reduced stress-induced neuroinflammation. ${ }^{45}$ Thus, TLR4 can be activated in response to stress, not only by pathogens, and is involved in stress-induced inflammation, including in the central nervous system.

There is much evidence linking an activated inflammatory response with suicidal behavior. Elevated levels of inflammatory cytokines, particularly interleukin-6 (IL-6), were found in the blood and CSF of patients who attempted suicide compared with nonsuicidal depressed patients and controls. ${ }^{60-64}$ Elevated markers of inflammation and microglial activation also were found in postmortem brains of suicide victims. ${ }^{65-67}$ Conversely, therapeutic administration of cytokines increases suicide risk. ${ }^{68-71}$ Particularly interesting is the recent finding from a postmortem brain study that protein expression of TLR4 is higher in depressed suicide victims than in depressed nonsuicide subjects and controls. ${ }^{72}$ Notably, alterations in genes involved in inflammation have been found to be associated with suicidal behavior in multiple studies of potential candidate genes. ${ }^{7-76}$ In addition, inflammation activates the enzyme indoleamine-2,3-dioxygenase, which catalyzes the formation of kynurenine, and plasma kynurenine levels were higher in depressed patients with a history of suicide attempts than in nonsuicidal depressed patients and healthy controls. ${ }^{77}$ The authors suggested that elevated kynurenine levels may be a marker of suicide attempt risk, independent of depression severity, and that kynurenine metabolites may 
contribute to the aggression/impulsivity and neurocognitive deficits proposed as endophenotypes associated with suicidal behavior. ${ }^{1,18,77-79}$ Thus, multiple lines of evidence demonstrate a consistent relationship between elevated markers of inflammation and suicidal behavior. Therefore, it is important to identify which components of suicidal behavior may be induced by activation of the inflammatory response.

\section{AGGRESSIVE BEHAVIOR}

Aggression has been linked to suicidal behavior in many studies ${ }^{1,3-5,7,8,79}$ and an increasing number of reports demonstrate that inflammation is associated with increased aggressive behaviors. $^{80}$ Elevated aggressive traits were associated with increased serum TNF, ${ }^{81}$ with the inflammatory marker C-reactive protein, ${ }^{82-84}$ and with multiple cytokines. ${ }^{84,85}$ Increased serum IL-6 levels correlated with personality traits of aggression in healthy controls $^{83}$ and with aggression traits in female patients with eating disorders. ${ }^{86}$ Furthermore, aggressive traits were increased in patients treated with cytokines therapeutically. ${ }^{87,88}$ Thus, in humans, aggressive behaviors are well correlated with increased markers of inflammation.

A few studies of rodents have also examined links between aggression and inflammation. In rodents, aggression is often measured using the social dominance tube test and the aggression test. Mice bred for high aggression had increased cytokine levels ${ }^{89}$ and knockout of both tumor necrosis factor receptor-1 and tumor necrosis factor receptor-2 resulted in the remarkable absence of aggressive behavior. ${ }^{90}$ Thus, there appears to be a strong link between aggression and activation of the inflammatory system in rodents, but further studies are needed to verify this association and to delineate which inflammatory molecules mediate the interaction and the mechanisms that are involved.

Substantial evidence shows that lithium can reduce aggressive behavior. Lithium is well documented to reduce aggressive behavior in a variety of human populations, for example, children, adults and the elderly, which has been related to its antisuicidal actions. ${ }^{5,6,8,91,92}$ As reviewed in detail previously, ${ }^{5,92,93}$ many studies have shown that aggressive behavior in rodents also is consistently reduced by lithium treatment. Thus, lithium significantly reduces aggressive traits and inflammation, but these two outcomes of lithium administration have not yet been examined together.

\section{IMPULSIVE BEHAVIOR}

As noted in the Introduction, impulsive behavior may frequently be an important component of suicidal behavior. Only a limited number of studies have tested if there is a relationship between inflammation and impulsive behavior. In a study of nearly 5000 individuals, elevated levels of IL- 6 were associated with impulsivity-related traits. ${ }^{94}$ A novel study of 5652 people over a period of 3 years identified a strong correlation between impulsiveness and increased lymphocyte numbers that are indicative of immune activation, and the authors concluded that 'impulsiveness was a predictor of chronic inflammation'. ${ }^{95}$

Links between inflammation and impulsive behavior appear not to have been examined in animal models, but there is evidence that lithium administration reduces impulsive behavior in humans and rodents. Three controlled studies of lithium in humans concluded that lithium reduces impulsive behavior, but further studies would strengthen this conclusion. ${ }^{96-98}$ In rodents, impulsive behavior exemplified by choosing a small or poor reward that is available immediately, in preference to a larger but delayed reward, is often measured using the three-choice serial reaction time task, ${ }^{99}$ in which mice are trained to respond to a flash of light occurring in one of three locations with a nose poke, which releases a food reward. In the subsequent test phase, mice are trained to choose between two light cues, one giving a larger food reward than the other. In subsequent trials, the delivery of the larger food reward is delayed, so mice must choose the immediate smaller reward or the delayed larger reward, and wildtype mice predominantly choose the latter. Increased impulsive behavior results in mice choosing the immediate smaller reward rather than the delayed larger reward. There is some indication that lithium treatment reduces impulsive behavior in rodents, but the data are limited. Lithium administration suppressed impulsive behavior in the three-choice serial reaction time task in male Wistar/ST rats, a strain that has been shown to be more impulsive than Lister hooded rats. ${ }^{100}$ Lithium reduced premature responses and increased the latency of the correct responses in the threechoice serial reaction time task in male Wistar/ST rats, without affecting response latency and without affecting the amount of food consumption or other motivation-related measures. ${ }^{101}$ Lithium also reduced impulsivity in mice in the delay discounting task in which mice receive larger rewards after a delayed response than after an immediate response. ${ }^{102}$ Thus, the links between impulsive behavior and inflammation, as well as its control by lithium, remain sparse but supportive of these associations.

\section{DEPRESSIVE BEHAVIOR}

Depression is often linked with suicidal behavior, although, in contrast to the commonly held assumption, many suicidal patients are not depressed. ${ }^{1,4,5,7,9,78,103}$ There is abundant evidence that inflammation is associated with the onset and severity of depression, as inflammatory molecules are upregulated in the serum and postmortem brains of depressed patients, as discussed in detail in several reviews. ${ }^{104-109}$ Furthermore, administration of interferon-a to bolster immunity induces depression in susceptible people. ${ }^{103,110}$ Moreover, LPS administration induces symptoms of depression in humans, ${ }^{111}$ and a mild stimulation of the primary host defense system has negative effects on emotion, which is thought to be caused by elevated cytokines. ${ }^{110,112}$ As noted above, psychological stresses that can induce depression increase inflammatory cytokine production in humans and rodents. ${ }^{113,114}$ Inflammation in patients with major depression is associated with resistance to antidepressant treatment, and anti-inflammatory drugs can improve antidepressant actions. ${ }^{106-108,114-116}$ Raison and Miller ${ }^{46}$ recently summarized results demonstrating that many genetic changes identified in patients with major depressive disorder involve the inflammatory system. In rodents, administration of inflammatory cytokines or the inflammation-stimulant LPS causes depression-like behaviors that are attenuated by antidepressants. $^{105}$ Specific inflammatory cytokines that have been identified as promoters of depression-like behavior in rodents include IL-6, ${ }^{117} \mathrm{TNFa}^{118}$ and IL- $1 \beta .{ }^{119}$ Thus, there is much evidence that inflammation can precipitate depression and impair therapeutic responses.

Lithium is not used therapeutically as a direct antidepressant, but is often used to augment antidepressants in treatmentresistant depression, and inflammation is reduced by lithium. In mice, lithium has a wide variety of antidepressant-like effects. For example, in mice, lithium administration produces antidepressantlike effects in the learned helplessness paradigm ${ }^{120}$ and in the forced swim test. ${ }^{121}$ The antidepressant actions of lithium are often attributed to its action as an inhibitor of glycogen synthase kinase-3 (GSK3), as discussed in the following section, because pharmacological or molecular inhibition of GSK3 has similar antidepressant effects in animal models.

\section{GSK3 INHIBITORS REDUCE INFLAMMATION}

GSK3 refers to two paralogs, GSK3 $a$ and GSK3 $\beta$, that are encoded by different genes but retain $85 \%$ homology and are commonly 
referred to as isoforms. GSK3 is primarily regulated by phosphorylation on serine-21-GSK3 $a$ and serine-9-GSK3 $\beta$, which inhibits GSK3 activity. Homozygous GSK3a/ $\beta^{21 A / 21 A / 9 A / 9 A}$ knockin mice express both GSK3 isoforms with serine-to-alanine mutations at these sites, S9A-GSK3 $\beta$ and S21A-GSK3a. This maintains GSK3 maximally active, since it cannot be inhibited by serine phosphorylation, but within the physiological range because GSK3 is expressed at normal levels. ${ }^{122}$ GSK3 may be a feasible therapeutic target to diminish suicidal behaviors because it promotes several suicide-linked behaviors in rodents and promotes inflammation, and lithium is a well-established inhibitor of GSK3, which may contribute to the capacity of lithium to reduce suicide.

A variety of evidence has raised the possibility that activated GSK3 may contribute to suicidal behaviors. GSK3 is activated in mouse brain by stress, ${ }^{123}$ a response that may promote suicidelinked behaviors, and GSK3 $\beta$ activity was found to be elevated in postmortem brains of depressed suicide victims. ${ }^{124}$ Clear evidence has demonstrated that GSK3 promotes aggressive behaviors, as reduced expression of either GSK3 isoform decreased aggressive behaviors in mice. ${ }^{125,126}$ The contribution of GSK3 to impulsive behaviors has yet to be examined, except for the studies of lithium discussed above, but an evaluation of SNPs in the GSK3 $\beta$ gene revealed that a genetic variability in the GSK3 $\beta$ gene is associated with increased impulsive behavior in patients with bipolar disorder. ${ }^{127}$ Many studies have shown that GSK3 promotes depression-like behaviors in rodents. ${ }^{128}$ These include clear antidepressant effects of a variety of new small molecule inhibitors of GSK3, in addition to lithium, in rodents, ${ }^{121,129-132}$ including on depressive behavior exhibited by tryptophan hydroxylase-2 mutant mice with deficient serotonin. ${ }^{125}$ Also, overexpression of a dominant-negative mutant of GSK3 to reduce GSK3 actions promoted resilience in the social defeat stress test of depression-like behavior. ${ }^{133}$ In addition, inhibition of GSK3 is required for the rapid antidepressant effect of ketamine in the learned helplessness model of depression in mice. ${ }^{120}$ Antidepressants increase serotoninergic signaling, which inhibits GSK3 by increasing its serine phosphorylation, and increase signaling by Wnt2, which inhibits GSK3 in the Wnt signaling pathway. ${ }^{134,135}$ Importantly, antidepressants inhibit GSK3 in mouse brain after in vivo administration of clinically relevant doses. ${ }^{125,135}$ Furthermore, oppositely to inhibiting GSK3, expression of constitutively active GSK3 in mice results in increased susceptibility to stressinduced depression-like behavior in mice. ${ }^{123}$

Lithium is an established inhibitor of GSK3, and lithium and other GSK3 inhibitors are remarkably effective in reducing inflammation. Therapeutic levels of lithium, $\sim 1 \mathrm{~mm}$, inhibit GSK3 both directly ${ }^{136,137}$ and by an indirect mechanism that causes increased inhibitory serine phosphorylation of GSK3. ${ }^{138,139}$ GSK3 inhibitors have been shown to be effective anti-inflammatory drugs, reducing by $67-90 \%$ inflammatory IL-6, IL-1 $\beta$ and TNFa production by microglia, ${ }^{140}$ astrocytes, ${ }^{141-146}$ human monocytes and peripheral blood mononuclear cells ${ }^{147}$ and other immune cells. ${ }^{143,146-149}$ Remarkably, in vivo administration of lithium provided protection from endotoxin shock sufficiently enough to allow the survival of most mice from an otherwise lethal (LD100) dose of LPS. ${ }^{147}$ Thus, GSK3 inhibition effectively reduces inflammation throughout the periphery and the central nervous system. ${ }^{150}$ Reduced LPS-induced inflammatory cytokines attained by inhibiting GSK3 was found to be due to inhibition of the transcriptional activity of NF-KB, a transcription factor that mediates upregulation of many inflammatory molecules, ${ }^{147}$ in accordance with reports that GSK3 promotes NF-kB activity, as we reviewed. ${ }^{151}$ GSK3 inhibitors also block signal transducer and activator of transcription-3 (STAT3) activation, a key transcription factor in inflammatory signaling. ${ }^{141}$ Remarkably, GSK3 regulates the anti-inflammatory cytokine IL-10 in an opposite manner, so GSK3 inhibition increases anti-inflammatory IL-10 levels three- to fourfold in vivo and in vitro. ${ }^{147}$ This is mediated by GSK3 inhibition of the CREB and AP-1 transcription factors to reduce their expression of anti-inflammatory IL-10, which underlies the increase in IL-10 levels induced by GSK3 inhibitors. ${ }^{147,152}$ The anti-inflammatory actions of GSK3 inhibitors likely contribute to their beneficial effects that have been found in multiple animal models of inflammatory diseases, including endotoxic shock, ${ }^{147}$ arthritis and peritonitis, ${ }^{152,153}$ endotoxemia, ${ }^{154}$ colitis $^{155}$ and traumatic brain injury. ${ }^{156}$ Furthermore, GSK3 inhibitors alleviate inflammatory disease severity in the mouse model of multiple sclerosis. ${ }^{146,157}$

In summary, GSK3 may be a feasible therapeutic intervention for suicidal behavior. GSK3 is activated by stress, is a strong promoter of inflammation, promotes in rodents aggressive and depression-like behaviors, and is inhibited by lithium, which diminishes suicidal behavior.

\section{PERSPECTIVE}

Altogether, there is substantial evidence that suicidal behavior and individual impulsivity, aggression and depression are all associated with increased inflammation, which itself can be induced by stress. Thus, we propose the concept that stress activates GSK3 and induces inflammation, which, in turn, promotes the suicide-linked endophenotypes of impulsivity, aggression and depression-like behaviors. We speculate that different inflammatory molecules are produced following different types of stress and that different inflammatory molecules may mediate each of the behavioral outcomes, perhaps accounting, in part, for why not all suicidal patients exhibit each behavior. Furthermore, it is likely that differential effects of inflammatory molecules on the specific brain regions and neural circuits that mediate each of the suicide-linked behaviors influence the cumulative behavioral outcome, which also must be regulated by genetic and epigenetic characteristics of affected subjects. Identification of the inflammatory and behavioral responses to stress that are attenuated by lithium may begin to provide information about its mechanism for reducing suicidal behavior, and why it is not effective in all patients. Furthermore, we suggest that inhibition of inflammatory signaling and inhibition of GSK3 may provide mechanisms to diminish in tandem both the inflammatory response to stress and suicide-related behaviors.

\section{CONFLICT OF INTEREST}

The authors declare no conflict of interest.

\section{ACKNOWLEDGMENTS}

Research in the authors' laboratories was supported by grants from the NIMH (MH038752, MH090236, MH095380).

\section{REFERENCES}

1 Mann JJ. Neurobiology of suicidal behaviour. Nat Rev Neurosci 2003; 4: 819-828.

2 Harris EC, Barraclough B. Suicide as an outcome for mental disorders. A meta-analysis. Br J Psychiatry 1997; 170: 205-228.

3 Koller G, Preuss UW, Bottlender M, Wenzel K, Soyka M. Impulsivity and aggression as predictors of suicide attempts in alcoholics. Eur Arch Psychiatry Clin Neurosci 2002; 252: 155-160.

4 Joiner TE Jr, Brown JS, Wingate LR. The psychology and neurobiology of suicidal behavior. Annu Rev Psychol 2005; 56: 287-314.

5 Kovacsics CE, Gottesman II, Gould TD. Lithium's antisuicidal efficacy: elucidation of neurobiological targets using endophenotype strategies. Annu Rev Pharmacol Toxicol 2009; 49: 175-198.

6 Tondo L, Baldessarini RJ. Long-term lithium treatment in the prevention of suicidal behavior in bipolar disorder patients. Epidemiol Psichiatr Soc 2009; 18: 179-183. 
7 Malkesman O, Pine DS, Tragon T, Austin DR, Henter ID, Chen G et al. Animal models of suicide-trait-related behaviors. Trends Pharmacol Sci 2009; 30: 165-173.

8 Müller-Oerlinghausen B, Lewitzka U. Lithium reduces pathological aggression and suicidality: a mini-review. Neuropsychobiology 2010; 62: 43-49.

9 Dalca IM, McGirr A, Renaud J, Turecki G. Gender-specific suicide risk factors: a case-control study of individuals with major depressive disorder. J Clin Psychiatry 2013; 74: 1209-1216.

10 De Jager PL, Bennett DA. An inflection point in gene discovery efforts for neurodegenerative diseases: from syndromic diagnoses toward endophenotypes and the epigenome. JAMA Neurol 2013; 70: 719-726.

11 Kannan G, Sawa A, Pletnikov MV. Mouse models of gene-environment interactions in schizophrenia. Neurobiol Dis 2013; 57: 5-11.

12 Gershon S, Chengappa KN, Malhi GS. Lithium specificity in bipolar illness: a classic agent for the classic disorder. Bipolar Disord 2009; 11(Suppl 2): 34-44.

13 Cipriani A, Pretty H, Hawton K, Geddes JR. Lithium in the prevention of suicidal behavior and all-cause mortality in patients with mood disorders: a systematic review of randomized trials. Am J Psychiatry 2005; 162: 1805-1819.

14 Baldessarini RJ, Tondo L, Davis P, Pompili M, Goodwin FK, Hennen J et al. Decreased risk of suicides and attempts during long-term lithium treatment: a meta-analytic review. Bipolar Disord 2006; 8: 625-639.

15 Guzzetta F, Tondo L, Centorrino F, Baldessarini RJ. Lithium treatment reduces suicide risk in recurrent major depressive disorder. J Clin Psychiatry 2007; 68: 380-383.

16 Cipriani A, Hawton K, Stockton S, Geddes JR. Lithium in the prevention of suicide in mood disorders: updated systematic review and meta-analysis. BMJ 2013; 346: $\mathrm{f} 3646$.

17 Vita A, De Peri L, Sacchetti E. Lithium in drinking water and suicide prevention: a review of the evidence. Int Clin Psychopharmacol 2014 (in press).

18 Mann JJ. The serotonergic system in mood disorders and suicidal behaviour. Philos Trans R Soc Lond B Biol Sci 2013; 368: 20120537.

19 Nguyen KT, Deak T, Owens SM, Kohno T, Fleshner M, Watkins LR et al. Exposure to acute stress induces brain interleukin-1 beta protein in the rat. $J$ Neurosci 1998 ; 18: $2239-2246$

20 Nguyen KT, Deak T, Will MJ, Hansen MK, Hunsaker BN, Fleshner M et al. Timecourse and corticosterone sensitivity of the brain, pituitary, and serum interleukin-1 beta protein response to acute stress. Brain Res 2000; 859: 193-201.

21 Quan N, Avitsur R, Stark JL, He L, Shah M, Caligiuri M et al. Social stress increases the susceptibility to endotoxic shock. J Neuroimmunol 2001; 115: 36-45.

22 Johnson JD, O'Connor KA, Deak T, Stark M, Watkins LR, Maier SF et al. Prior stressor exposure sensitizes LPS-induced cytokine production. Brain Behav Immun 2002; 16: 461-476.

23 Madrigal JL, Hurtado O, Moro MA, Lizasoain I, Lorenzo P, Castrillo A et al. The increase in TNF-alpha levels is implicated in NF-kappaB activation and inducible nitric oxide synthase expression in brain cortex after immobilization stress. Neuropsychopharmacology 2002; 26: 155-163.

24 Bierhaus A, Wolf J, Andrassy M, Rohleder N, Humpert PM, Petrov D et al. A mechanism converting psychosocial stress into mononuclear cell activation. Proc Natl Acad Sci USA 2003; 100: 1920-1925.

25 Johnson JD, O'Connor KA, Hansen MK, Watkins LR, Maier SF. Effects of prior stress on LPS-induced cytokine and sickness responses. Am J Physiol Regul Integr Comp Physiol 2003; 284: 422-432.

26 Kiecolt-Glaser JK, Preacher KJ, MacCallum RC, Atkinson C, Malarkey WB, Glaser R et al. Chronic stress and age-related increases in the proinflammatory cytokine IL-6. Proc Natl Acad Sci USA 2003; 100: 9090-9095.

27 Johnson JD, O'Connor KA, Stark M, Watkins LR, Maier SF. The role of IL-1beta in stress-induced sensitization of proinflammatory cytokine and corticosterone responses. Neuroscience 2004; 127: 569-577.

28 Munhoz C, Madrigal JL, García-Bueno B, Pradillo JM, Moro MA, Lizasoain I et al. TNF-alpha accounts for short-term persistence of oxidative status in rat brain after two weeks of repeated stress. Eur J Neurosci 2004; 20: 1125-1130.

29 Avitsur R, Kavelaars A, Heijnen C, Sheridan JF. Social stress and the regulation of tumor necrosis factor-alpha secretion. Brain Behav Immun 2005; 19: 311-317.

30 Viswanathan K, Daugherty C, Dhabhar FS. Stress as an endogenous adjuvant: augmentation of the immunization phase of cell-mediated immunity. Int Immunol 2005; 17: 1059-1069.

31 Munhoz CD, Lepsch LB, Kawamoto EM, Malta MB, de Sá Lima L, Avellar MCW et al. Chronic unpredictable stress exacerbates lipopolysaccharide-induced activation of nuclear factor-кB in the frontal cortex and hippocampus via glucocorticoid secretion. J Neuroscience 2006; 26: 3813-3820.

32 Pace TW, Mletzko TC, Alagbe O, Musselman DL, Nemeroff CB, Miller AH et al. Increased stress-induced inflammatory responses in male patients with major depression and increased early life stress. Am J Psychiatry 2006; 163: 1630-1633.
33 Steptoe A, Hamer M, Chida Y. The effect of acute psychological stress on circulating inflammatory factors in humans: a review and meta-analysis. Brain Behav Immun 2007; 7: 901-912.

34 Miller GE, Chen E, Sze J, Marin T, Arevalo JM, Doll R et al. A functional genomic fingerprint of chronic stress in humans: blunted glucocorticoid and increased NF-kappaB signaling. Biol Psychiatry 2008; 64: 266-272.

35 Bailey MT, Kinsey SG, Padgett DA, Sheridan JF, Leblebicioglu B. Social stress enhances IL-1 $\beta$ and TNF- $a$ production by Porphyromonas gingivalis lipopolysaccharide-stimulated CD11b+ cells. Physiol Behav 2009; 98: 351-358.

36 Blandino P Jr, Barnum CJ, Solomon LG, Larish Y, Lankow BS, Deak T et al. Gene expression changes in the hypothalamus provide evidence for regionallyselective changes in IL-1 and microglial markers after acute stress. Brain Behav Immun 2009; 23: 958-968.

37 Mays JW, Bailey MT, Hunzeker JT, Powell ND, Papenfuss T, Karlsson EA et al. Influenza virus-specific immunological memory is enhanced by repeated social defeat. J Immunol 2010; 184: 2014-2025.

38 Miller GE, Chen E. Harsh family climate in early life presages the emergence of a proinflammatory phenotype in adolescence. Psychol Sci 2010; 21: 848-856.

39 Audet MC, Jacobson-Pick S, Wann BP, Anisman H. Social defeat promotes specific cytokine variations within the prefrontal cortex upon subsequent aggressive or endotoxin challenges. Brain Behav Immun 2011; 25: 1197-1205.

40 Irwin MR, Cole SW. Reciprocal regulation of the neural and innate immune systems. Nat Rev Immunol 2011; 11: 625-632.

41 Powell ND, Mays JW, Bailey MT, Hanke ML, Sheridan JF. Immunogenic dendritic cells primed by social defeat enhance adaptive immunity to influenza $A$ virus. Brain Behav Immun 2011; 25: 46-52.

42 Gárate I, García-Bueno B, Madrigal JL, Bravo L, Berrocoso E, Caso JR et al. Origin and consequences of brain Toll-like receptor 4 pathway stimulation in an experimental model of depression. J Neuroinflammation 2011; 8: 151.

43 Gárate I, Garcia-Bueno B, Madrigal JL, Caso JR, Alou L, Gomez-Lus ML et al. Stressinduced neuroinflammation: role of the Toll-like receptor-4 pathway. Biol Psychiatry 2013; 73: 32-43.

44 McQuaid RJ, Audet MC, Jacobson-Pick S, Anisman H. Environmental enrichment influences brain cytokine variations elicited by social defeat in mice. Psychoneuroendocrinology 2013; 38: 987-996.

45 Gárate I, García-Bueno B, Madrigal JL, Caso JR, Alou L, Gómez-Lus ML et al. Tolllike 4 receptor inhibitor TAK-242 decreases neuroinflammation in rat brain frontal cortex after stress. J Neuroinflammation 2014; 11: 8.

46 Raison $\mathrm{CL}$, Miller AH. The evolutionary significance of depression in Pathogen Host Defense (PATHOS-D). Mol Psychiatry 2013; 18: 15-37.

47 Akira S. TLR signaling. Curr Top Microbiol Immunol 2006; 311: 1-16.

48 Okun E, Griffioen KJ, Mattson MP. Toll-like receptor signaling in neural plasticity and disease. Trends Neurosci 2011; 34: 269-281.

49 Vabulas RM, Ahmad-Nejad P, Ghose S, Kirschning CJ, Issels RD, Wagner $\mathrm{H}$ et al. HSP70 as endogenous stimulus of the Toll/interleukin-1 receptor signal pathway. J Biol Chem 2002; 277: 15107-15112.

50 Jiang D, Liang J, Fan J, Yu S, Chen S, Luo Y et al. Regulation of lung injury and repair by Toll-like receptors and hyaluronan. Nat Med 2005; 11: 1173-1179.

51 Yang QW, Lu FL, Zhou Y, Wang L, Zhong Q, Lin S et al. HMBG1 mediates ischemia-reperfusion injury by TRIF-adaptor independent Toll-like receptor 4 signaling. J Cereb Blood Flow Metab 2011; 31: 593-605.

52 Gill R, Tsung A, Billiar T. Linking oxidative stress to inflammation: Toll-like receptors. Free Radic Biol Med 2010; 48: 1121-1132.

53 Bsibsi M, Ravid R, Gveric D, van Noort JM. Broad expression of Toll-like receptors in the human central nervous system. J Neuropathol Exp Neurol 2002; 61: 1013-1021.

54 Olson JK, Miller SD. Microglia initiate central nervous system innate and adaptive immune responses through multiple TLRs. J Immunol 2004; 173: 3916-3924.

55 Tang SC, Arumugam TV, Xu X, Cheng A, Mughal MR, Jo DG et al. Pivotal role for neuronal Toll-like receptors in ischemic brain injury and functional deficits. Proc Natl Acad Sci USA 2007; 104: 13798-13803.

56 Acosta C, Davies A. Bacterial lipopolysaccharide regulates nociceptin expression in sensory neurons. J Neurosci Res 2008; 86: 1077-1086.

57 Sloane JA, Blitz D, Margolin Z, Vartanian T. A clear and present danger: endogenous ligands of Toll-like receptors. Neuromolecular Med 2010; 12: 149-163.

58 van Noort JM, Bsibsi M. Toll-like receptors in the CNS: implications for neurodegeneration and repair. Prog Brain Res 2009; 175: 139-148.

59 Lehnardt S, Lehmann S, Kaul D, Tschimmel K, Hoffmann O, Cho S et al. Toll-like receptor 2 mediates CNS injury in focal cerebral ischemia. J Neuroimmunol 2007; 190: 28-33.

60 Nässberger L, Träskman-Bendz L. Increased soluble interleukin-2 receptor concentrations in suicide attempters. Acta Psychiatr Scand 1993; 88: 48-52.

61 Kim YK, Lee SW, Kim SH, Shim SH, Han SW, Choi SH et al. Differences in cytokines between non-suicidal patients and suicidal patients in major depression. Prog Neuropsychopharmacol Biol Psychiatry 2008; 32: 356-361. 
62 Lindqvist D, Janelidze S, Hagell P, Erhardt S, Samuelsson M, Minthon L et al. Interleukin- 6 is elevated in the cerebrospinal fluid of suicide attempters and related to symptom severity. Biol Psychiatry 2009; 66: 287-292.

63 Janelidze S, Mattei D, Westrin A, Traskman-Bendz L, Brundin L. Cytokine levels in the blood may distinguish suicide attempters from depressed patients. Brain Behav Immun 2011; 25: 335-339.

64 Lindqvist D, Janelidze S, Erhardt S, Träskman-Bendz L, Engström G, Brundin L et al. CSF biomarkers in suicide attempters--a principal component analysis. Acta Psychiatr Scand 2011; 124: 52-61.

65 Steiner J, Bielau H, Brisch R, Danos P, Ullrich O, Mawrin C et al. Immunological aspects in the neurobiology of suicide: elevated microglial density in schizophrenia and depression is associated with suicide. J Psychiatr Res 2008; 42: 151-157.

66 Tonelli LH, Stiller J, Rujescu D, Giegling I, Schneider B, Maurer K et al. Elevated cytokine expression in the orbitofrontal cortex of victims of suicide. Acta Psychiatr Scand 2008; 117: 198-206.

67 Pandey GN, Rizavi HS, Ren X, Fareed J, Hoppensteadt DA, Roberts RC et al. Proinflammatory cytokines in the prefrontal cortex of teenage suicide victims. $J$ Psychiatr Res 2012; 46: 57-63.

68 Baron DA, Hardie T, Baron SH. Possible association of interleukin-2 treatment with depression and suicide. J Am Osteopath Assoc 1993; 93: 799-800.

69 Janssen HL, Brouwer JT, van der Mast RC, Schalm SW. Suicide associated with ainterferon therapy for chronic viral hepatitis. J Hepatol 1994; 21: 241-243.

70 Dieperink E, Ho SB, Tetrick L, Thuras P, Dua K, Willenbring ML et al. Suicidal ideation during interferon- $a 2 b$ and ribavirin treatment of patients with chronic hepatitis C. Gen Hosp Psychiatry 2004; 26: 237-240.

71 Fragoso YD, Frota ER, Lopes JS, Noal JS, Giacomo MC, Gomes S et al. Severe depression, suicide attempts, and ideation during the use of interferon beta by patients with multiple sclerosis. Clin Neuropharmacol 2010; 33: 312-318.

72 Pandey GN, Rizavi HS, Ren X, Bhaumik R, Dwivedi Y. Toll-like receptors in the depressed and suicide brain. J Psychiatr Res 2014; 53: 62-68.

73 Mendlovic S, Mozes E, Eilat E, Doron A, Lereya J, Zakuth V et al. Immune activation in non-treated suicidal major depression. Immunol Lett 1999; 67: 105-108.

74 Sequeira A, Klempan T, Canetti L, ffrench-Mullen J, Benkelfat C, Rouleau GA et al. Patterns of gene expression in the limbic system of suicides with and without major depression. Mol Psychiatry 2007; 12: 640-655.

75 Thalmeier A, Dickmann M, Giegling I, Schneider B, M Hartmann A, Maurer K et al. Gene expression profiling of post-mortem orbitofrontal cortex in violent suicide victims. Int J Neuropsychopharmacol 2008; 11: 217-228.

76 Galfalvy H, Zalsman G, Huang YY, Murphy L, Rosoklija G, Dwork AJ et al. A pilot genome wide association and gene expression array study of suicide with and without major depression. World J Biol Psychiatry 2013; 14: 574-582.

77 Sublette ME, Galfalvy HC, Fuchs D, Lapidus M, Grunebaum MF, Oquendo MA et al. Plasma kynurenine levels are elevated in suicide attempters with major depressive disorder. Brain Behav Immun 2011; 25: 1272-1278.

78 Mann JJ, Currier DM. Stress, genetics and epigenetic effects on the neurobiology of suicidal behavior and depression. Eur Psychiatry 2010; 25: 268-271.

79 Mann JJ, Arango VA, Avenevoli S, Brent DA, Champagne FA, Clayton P et al. Candidate endophenotypes for genetic studies of suicidal behavior. Biol Psychiatry 2009; 65: 556-563.

80 Zalcman SS, Siegel A. Neurobiology of aggression and rage: role of cytokines. Brain Behav Immunity 2006; 20: 507-514.

81 Suarez EC, Lewis JG, Kuhn C. The relation of aggression, hostility, and anger to lipopolysaccharide-stimulated tumor necrosis factor (TNF)-alpha by blood monocytes from normal men. Brain Behav Immun 2002; 16: 675-684.

82 Coccaro EF. Association of C-reactive protein elevation with trait aggression and hostility in personality disordered subjects: a pilot study. J Psychiatr Res 2006; 40 460-465.

83 Marsland AL, Prather AA, Petersen KL, Cohen S, Manuck SB. Antagonistic characteristics are positively associated with inflammatory markers independently of trait negative emotionality. Brain Behav Immun 2008; 22: 753-761.

84 Coccaro EF, Lee R, Coussons-Read M. Elevated plasma inflammatory markers in individuals with intermittent explosive disorder and correlation with aggression in humans. JAMA Psychiatry 2014; 71: 158-165.

85 Mommersteeg PM, Vermetten E, Kavelaars A, Geuze E, Heijnen CJ. Hostility is related to clusters of T-cell cytokines and chemokines in healthy men. Psychoneuroendocrinology 2008; 33: 1041-1050.

86 Ahrén-Moonga J, Lekander M, von Blixen N, Rönnelid J, Holmgren S, af Klinteberg $B$ et al. Levels of tumour necrosis factor-alpha and interleukin- 6 in severely ill patients with eating disorders. Neuropsychobiology 2011; 63: 8-14.

87 McHutchison JG, Gordon SC, Schiff ER, Shiffman ML. Interferon $a-2 b$ alone or in combination with ribavirin as initial treatment for chronic hepatitis $\mathrm{C}$. Hepatitis Interventional Therapy Group. New Eng J Med 1998; 339: 1485-1492.
88 Kraus MR, Schäfer A, Faller H, Csef $H$, Scheurlen M. Psychiatric symptoms in patients with chronic hepatitis $C$ receiving interferon alfa-2b therapy. J Clin Psychiatry 2003; 64: 708-714.

89 Petitto JM, Lysle DT, Gariepy JL, Lewis MH. Association of genetic differences in social behavior and cellular immune responsiveness: effects of social experience. Brain Behav Immun 1994; 8: 111-122.

90 Patel A, Siegel A, Zalcman SS. Lack of aggression and anxiolytic-like behavior in TNF receptor (TNF-R1 and TNF-R2) deficient mice. Brain Behav Immun 2010; 24: 1276-1280.

91 Bierbrauer J Nilsson A Müller-Oerlinghausen B Bauer M. Therapeutic and prophylactic effects of lithium on pathological aggression. In: Bauer, M, Grof, P, Müller-Oerlinghausen, B (eds). Lithium in Neuropsychiatry. Informa Healthcare, Abingdon, UK, 2006. 227-236.

92 Kovacsics CE, Gould TD. Shock-induced aggression in mice is modified by lithium. Pharmacol Biochem Behav 2010; 94: 380-386.

93 O'Donnell KC, Gould TD. The behavioral actions of lithium in rodent models: leads to develop novel therapeutics. Neurosci Biobehav Rev 2007; 31: 932-962.

94 Sutin AR, Terracciano A, Deiana B, Naitza S, Ferrucci L, Uda M et al. High neuroticism and low conscientiousness are associated with interleukin-6. Psychol Med 2010; 40: 1485-1493.

95 Sutin AR, Milaneschi Y, Cannas A, Ferrucci L, Uda M, Schlessinger D et al. Impulsivity-related traits are associated with higher white blood cell counts. $J$ Behav Med 2012; 35: 616-623.

96 Dorrego MF, Canevaro L, Kuzis G, Sabe L, Starkstein SE. A randomized, doubleblind, crossover study of methylphenidate and lithium in adults with attentiondeficit/hyperactivity disorder: preliminary findings. J Neuropsychiatry Clin Neurosci 2002; 14: 289-295.

97 Swann AC, Bowden CL, Calabrese JR, Dilsaver SC, Morris DD. Pattern of response to divalproex, lithium, or placebo in four naturalistic subtypes of mania. Neu ropsychopharmacology 2002; 26: 530-536.

98 Hollander E, Pallanti S, Allen A, Sood E, Baldini Rossi N. Does sustained-release lithium reduce impulsive gambling and affective instability versus placebo in pathological gamblers with bipolar spectrum disorders? Am J Psychiatry 2005 162: 137-145.

99 Higgins GA, Breysse N. Rodent model of attention: the 5-choice serial reaction time task. Curr Protoc Pharmacol 2008; Chapter 5, Unit 5.49.

100 Galtress T, Garcia A, Kirkpatrick K. Individual differences in impulsive choice and timing in rats. J Exp Anal Behav 2012; 98: 65-87.

101 Ohmura Y, Tsutsui-Kimura I, Kumamoto H, Minami M, Izumi T, Yamaguchi T et al. Lithium, but not valproic acid or carbamazepine, suppresses impulsive-like action in rats. Psychopharmacology 2012; 219: 421-432.

102 Halcomb ME, Gould TD, Grahame NJ. Lithium, but not valproate, reduces impulsive choice in the delay discounting task in mice. Neuropsychopharmacology 2013; 38: 1937-1944.

103 Hayley S, Poulter M.O, Merali Z, Anisman H. The pathogenesis of clinical depression: stressor- and cytokine-induced alterations of neuroplasticity. Neu roscience 2005; 135: 659-678.

104 Schiepers OJ, Wichers MC, Maes M. Cytokines and major depression. Prog Neuropsychopharmacol Biol Psychiatry 2005; 29: 201-217.

105 Dantzer R, Kelley KW. Twenty years of research on cytokine-induced sickness behavior. Brain Behav Immun 2007; 21: 153-160.

106 Dantzer R, O'Connor JC, Freund GG, Johnson RW, Kelley KW. From inflammation to sickness and depression: when the immune system subjugates the brain. Nat Rev Neurosci 2008; 9: 46-56.

107 Miller AH, Maletic V, Raison CL. Inflammation and its discontents: the role of cytokines in the pathophysiology of major depression. Biol Psychiatry 2009; 65: 732-741.

108 Rivest S. Regulation of innate immune responses in the brain. Nat Rev Immunol 2009; 9: 429-439.

109 Shelton RC, Claiborne J, Sidoryk-Wegrzynowicz M, Reddy R, Aschner M, Lewis DA et al. Altered expression of genes involved in inflammation and apoptosis in frontal cortex in major depression. Mol Psychiatry 2011; 16: 751-762.

110 Lotrich FE, Ferrell RE, Rabinovitz M, Pollock BG. Risk for depression during interferon-alpha treatment is affected by the serotonin transporter polymorphism. Biol Psychiatry 2009; 65: 344-348.

111 Kullmann JS, Grigoleit JS, Lichte $\mathrm{P}$, Kobbe $\mathrm{P}$, Rosenberger $\mathrm{C}$, Banner $\mathrm{C}$ et al. Neural response to emotional stimuli during experimental human endotoxemia. Hum Brain Mapp 2013; 34: 2217-2227.

112 Reichenberg A, Yirmiya R, Schuld A, Kraus T, Haack M, Morag A et al. Cytokineassociated emotional and cognitive disturbances in humans. Arch Gen Psychiatry 2001; 58: 445-452.

113 Anisman H, Merali Z. Cytokines, stress and depressive illness: brain-immune interactions. Ann Med 2003; 35: 2-11. 
114 Gabbay V, Klein RG, Alonso CM, Babb JS, Nishawala M, De Jesus G et al. Immune system dysregulation in adolescent major depressive disorder. J Affect Disord 2009; 115: 177-182.

115 O'Brien SM, Scully P, Fitzgerald P, Scott LV, Dinan TG. Plasma cytokine profiles in depressed patients who fail to respond to selective serotonin reuptake inhibitor therapy. J Psychiatr Res 2007; 41: 326-331.

116 Roumestan C, Michel A, Bichon F, Portet K, Detoc M, Henriquet C et al. Antiinflammatory properties of desipramine and fluoxetine. Respir Res 2007; 3: 8-35.

117 Chourbaji S, Urani A, Inta I, Sanchis-Segura C, Brandwein C, Zink M et al. IL-6 knockout mice exhibit resistance to stress-induced development of depressionlike behaviors. Neurobiol Dis 2006; 23: 587-954.

118 Simen BB, Duman $\mathrm{CH}$, Simen AA, Duman RS. TNFa signaling in depression and anxiety: behavioral consequences of individual receptor targeting. Biol Psychiatry 2006; 59: 775-785.

119 Koo JW, Duman RS. Evidence for IL-1 receptor blockade as a therapeutic strategy for the treatment of depression. Curr Opin Investig Drugs 2009; 10: 664-671.

120 Beurel E, Song L, Jope RS. Inhibition of glycogen synthase kinase-3 is necessary for the rapid antidepressant effect of ketamine in mice. Mol Psychiatry 2011; 16: 1068-1070.

121 O'Brien WT, Harper AD, Jové F, Woodgett JR, Maretto S, Piccolo S et al. Glycogen synthase kinase- $3 \beta$ haploinsufficiency mimics the behavioral and molecular effects of lithium. J Neurosci 2004; 24: 6791-6798.

122 McManus EJ, Sakamoto K, Armit LJ, Ronaldson L, Shpiro N, Marquez R et al. Role that phosphorylation of GSK3 plays in insulin and Wnt signalling defined by knockin analysis. EMBO J 2005; 24: 1571-1583.

123 Polter A, Beurel E, Yang S, Garner R, Song L, Miller CA et al. Deficiency in the inhibitory serine-phosphorylation of glycogen synthase kinase-3 increases sensitivity to mood disturbances. Neuropsychopharmacology 2010; 35: 1761-1774.

124 Karege F, Perroud N, Burkhardt S, Schwald M, Ballmann E, La Harpe R et al. Alteration in kinase activity but not in protein levels of protein kinase $B$ and glycogen synthase kinase- $3 \beta$ in ventral prefrontal cortex of depressed suicide victims. Biol Psychiatry 2007; 61: 240-245.

125 Beaulieu JM, Zhang X, Rodriguiz RM, Sotnikova TD, Cools MJ, Wetsel WC et al. Role of GSK3 beta in behavioral abnormalities induced by serotonin deficiency. Proc Natl Acad Sci USA 2008; 105: 1333-1338.

126 Kaidanovich-Beilin O, Lipina TV, Takao K, van Eede M, Hattori S, Laliberté C et al. Abnormalities in brain structure and behavior in GSK-3a mutant mice. Mol Brain 2009; 2: 35.

127 Jiménez E, Arias B, Mitjans M, Goikolea JM, Roda E, Ruíz V et al. Association between GSK3 $\beta$ gene and increased impulsivity in bipolar disorder. Eur Neuropsychopharmacol 2014; 24: 510-518.

128 Jope RS. Glycogen synthase kinase-3 in the etiology and treatment of mood disorders. Front Mol Neurosci 2011; 4: 16-26.

129 Gould TD, Einat H, Bhat R, Manji HK. AR-A014418, a selective GSK-3 inhibitor, produces antidepressant-like effects in the forced swim test. Int J Neuropsychopharmacol 2004; 7: 387-390.

130 Kaidanovich-Beilin O, Milman A, Weizman A, Pick CG, Eldar-Finkelman H. Rapid antidepressive-like activity of specific glycogen synthase kinase-3 inhibitor and its effect on $\beta$-catenin in mouse hippocampus. Biol Psychiatry 2004; 55: 781-784.

131 Shapira M, Licht A, Milman A, Pick CG, Shohami E, Eldar-Finkelman H et al. Role of glycogen synthase kinase-3 $\beta$ in early depressive behavior induced by mild traumatic brain injury. Mol Cell Neurosci 2007; 34: 571-577.

132 Silva R, Mesquita AR, Bessa J, Sousa JC, Sotiropoulos I, Leão P et al. Lithium blocks stress-induced changes in depressive-like behavior and hippocampal cell fate: the role of glycogen-synthase-kinase-3ß. Neuroscience 2008; 152: 656-669.

133 Wilkinson MB, Dias C, Magida J, Mazei-Robison M, Lobo M, Kennedy P et al. A novel role of the WNT-dishevelled-GSK3 $\beta$ signaling cascade in the mouse nucleus accumbens in a social defeat model of depression. J Neurosci 2011; 31: 9084-9092.

134 Okamoto H, Voleti B, Banasr M, Sarhan M, Duric V, Girgenti M. J et al. Wnt2 expression and signaling is increased by different classes of antidepressant treatments. Biol Psychiatry 2010; 68: 521-527.

135 Li X, Zhu W, Roh MS, Friedman AB, Rosborough K, Jope RS et al.. In vivo regulation of glycogen synthase kinase-3 $\beta$ (GSK3 $\beta$ ) by serotonergic activity in mouse brain. Neuropsychopharmacology 2004; 29: 1426-1431.

136 Klein PS, Melton DA. A molecular mechanism for the effect of lithium on development. Proc Natl Acad Sci USA 1996; 93: 8455-8459.
137 Stambolic V, Ruel L, Woodgett JR. Lithium inhibits glycogen synthase kinase-3 activity and mimics wingless signalling in intact cells. Curr Biol 1996; 6: 1664-1668

138 De Sarno P, Li X, Jope RS. Regulation of Akt and glycogen synthase kinase-3 $\beta$ phosphorylation by sodium valproate and lithium. Neuropharmacology 2002; 43: 1158-1164.

139 Jope RS. Lithium and GSK3: one inhibitor, two inhibitory actions, multiple outcomes. Trends Pharmacol Sci 2003; 24: 441-443.

140 Yuskaitis CJ, Jope RS. Glycogen synthase kinase-3 regulates microglial migration, inflammation, and inflammation-induced neurotoxicity. Cell Signal 2009; 21: 264-273.

141 Beurel E, Jope RS. Differential regulation of STAT family members by glycogen synthase kinase-3. J Biol Chem 2008; 283: 21934-21944.

142 Beurel E, Jope RS. Lipopolysaccharide-induced interleukin-6 production is controlled by glycogen synthase kinase-3 and STAT3 in the brain. J Neuroinflammation 2009; 6: 9-20.

143 Beurel E, Jope RS. Glycogen synthase kinase-3 promotes the synergistic action of interferon- $\gamma$ on lipopolysaccharide-induced IL-6 production in RAW264.7 cells. Cell Signalling 2009; 21: 978-985.

144 Beurel E, Jope RS. Glycogen synthase kinase-3 controls inflammatory tolerance in astrocytes. Neuroscience 2010; 169: 1063-1070.

145 Beurel E, Michalek SM, Jope RS. Innate and adaptive immune responses regulated by glycogen synthase kinase-3 (GSK3). Trends Immunol 2010; 31: 24-31.

146 Beurel E, Wen-I Y, Michalek SM, Harrington LE, Jope RS. Glycogen synthase kinase- 3 is an early determinant in the differentiation of pathogenic Th17 cells. $J$ Immunol 2011; 186: 1391-1398.

147 Martin M, Rehani K, Jope RS, Michalek SM. Toll-like receptor-mediated cytokine production is differentially regulated by glycogen synthase kinase 3 . Nat Immunol 2005; 6: 777-784.

148 Tsai C.C, Kai J.I, Huang W.C, Wang C.Y, Wang Y, Chen C.L et al. Glycogen synthase kinase-3 $\beta$ facilitates IFN- $\gamma$-induced STAT1 activation by regulating Src homology2 domain-containing phosphatase 2. J Immunol 2009; 183: 856-864.

149 Turnquist HR, Cardinal J, Macedo C, Rosborough BR, Sumpter TL, Geller DA et al. mTOR and GSK-3 shape the CD4+ T-cell stimulatory and differentiation capacity of myeloid DCs after exposure to LPS. Blood 2010; 115: 4758-4769.

150 Beurel E. Regulation by glycogen synthase kinase- 3 of inflammation and T cells in CNS diseases. Front Mol Neurosci 2011; 4: 18.

151 Beurel E, Jope RS. The paradoxical pro- and anti-apoptotic actions of GSK3 in the intrinsic and extrinsic apoptosis signaling pathways. Prog Neurobiol 2006; 79: 173-189.

152 Hu X, Paik PK, Chen J, Yarilina A, Kockeritz L, Lu TT et al. IFN- $\gamma$ suppresses IL-10 production and synergizes with TLR2 by regulating GSK3 and CREB/AP-1 proteins. Immunity 2006; 24: 563-574.

153 Cuzzocrea S, Mazzon E, Di Paola R, Muia C, Crisafulli C, Dugo L et al. Glycogen synthase kinase-3 $\beta$ inhibition attenuates the degree of arthritis caused by type II collagen in the mouse. Clin Immunol 2006; 120: 57-67.

154 Dugo L, Collin M, Allen DA, Patel NS, Bauer I, Mervaala EM et al. GSK-3ß inhibitors attenuate the organ injury/dysfunction caused by endotoxemia in the rat. Crit Care Med 2005; 33: 1903-1912.

155 Whittle BJ, Varga C, Posa A, Molnar A, Collin M, Thiemermann C et al. Reduction of exp erimental colitis in the rat by inhibitors of glycogen synthase kinase- $3 \beta$. $B r$ J Pharmacol 2006; 147: 575-582.

156 Yu F, Wang Z, Tchantchou F, Chiu CT, Zhang Y, Chuang DM et al. Lithium ameliorates neurodegeneration, suppresses neuroinflammation, and improves behavioral performance in a mouse model of traumatic brain injury. $J$ Neurotrauma 2012; 29: 362-374.

157 Beurel E, Kaidanovich-Beilin O, Yeh WI, Song L, Palomo V, Michalek SM et al. Regulation of Th1 cells and experimental autoimmune encephalomyelitis (EAE) by glycogen synthase kinase-3. J Immunol 2013; 190: 5000-5011.

This work is licensed under a Creative Commons AttributionBY NC ND NonCommercial-NoDerivs 4.0 International License. The images or other third party material in this article are included in the article's Creative Commons license, unless indicated otherwise in the credit line; if the material is not included under the Creative Commons license, users will need to obtain permission from the license holder to reproduce the material. To view a copy of this license, visit http:// creativecommons.org/licenses/by-nc-nd/4.0/ 